\title{
橋脚による堰き上げ効果の再現性に着目した 数值解析モデルの比較 \\ COMPARISON OF VARIOUS NUMERICAL MODELS FOR PREDICTION OF WATER ELEVATION AROUND BRIDGE PIERS
}

\author{
木村 一郎 1 ・細田 尚 2 - 音田 慎一郎 3 \\ Ichiro KIMURA, Takashi HOSODA and Shinichiro ONDA

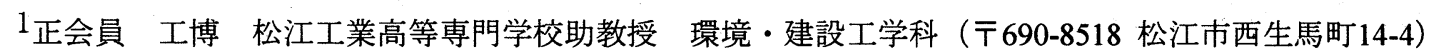 \\ 2 正会員 工博 京都大学大学院教授 工学研究科都市社会工学専攻（广606-8501 京都市左京区吉田本町） \\ 3 学生員 工修 京都大学大学院工学研究科博士課程学生（广606-8501 京都市左京区吉田本町）
}

\begin{abstract}
This paper describes the comparisons of numerical models focusing on the water elevation around a bridge pier. Three different numerical models, namely, 2D plane model, Qasi-3D model (3D model with hydrostatic assumption) and Full-3D model, are considered. As turbulence models, a simple 0-equation model is used for the 2D plane model and a non-linear k-e model with effects of strain and rotation parameters are applied for the quasi-3D and full-3D models. First, laboratory test is carried out to obtain data for verification under $\operatorname{Re}=8400$ and $\mathrm{Fr}=0.54$. The computations are performed in the same conditions of the laboratory test. The numerical results show that the $2 \mathrm{D}$ and full 3D models can capture well the height of water elevation at the upstream region of the cylinder though the quasi3D model under-predicts it. The 2D model overestimates the depth of the hollow behind the cylinder. The quasi-3D model considerably over-estimates the length of the re-circulation zone.
\end{abstract}

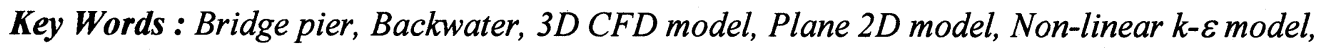
Karman vortex, Horseshoe vortex

\section{1. はじめに}

近年のパーソナルコンピュータの高性能化, 低価格化に 伴って, CFDの分野においても従来スパコンの領域であっ た3次元解析が急速に普及しようとしている.このことは非線 形乱流モデルやLES, DNSの発達と㥵まって, 特に乱流に 関連する現象の解明に大きく寄与している.一方, 従来から 数值水理解析の一つの主流ともいえる平面二次元モデル においても，2次流の影響の取り込み ${ }^{11}$ や, 鉛直加速度を考 慮したモデル22), 水深積分非線形ゼロ方程式モデル ${ }^{33}$ のなど が提案され，適用範囲を広げつつある.これらは高性能二 次元モデルとでもいうべきものであり, その導出過程におい て高度の知識が要求されるが, 一旦モデルが導出され, 解 析プログラムに組み込まれさえすれば, 従来の二次元モデ ルと遜色ない計算速度が得られる. 三次元解析が計算時間 や計算機容量の点で今なお制約が大きいことを考えると， 実用的な側面での魅力が大きい. このように, 水理数值解 析モデルは, 三次元モデルの普及と二次元モデルの高性 能化といら二極化が進みつつあるともみてとれる. 技術者に とって, モデルの選択の幅が広がったことは好ましいが, 状
況に応じて適切にモデルを取捨選択していく能力が要求さ れてきたともいえよう。

ところで, 三次元モデルの計算時間の大半は圧力の収束 計算に費やされるのが通例である. もし, 圧力分布に静水 圧を仮定できるなら, 圧力の収束計算が不要になり, かつ鉛 直方向の運動方程式が簡易化されるため, 計算時間が格 段に短縮される.このようなモデルを準三次元モデルと呼ぶ ことがあり, 本研究でもこの呼称を用いることにする. 準三次 元モデルは動水圧の影響の小さい流れにおいてで三次元 流動場を得るのに適しており, ちょうど平面二次元モデルと 三次元モデルの隙間を埋めるモデルともみなせよう. 平面 二次元モデルが高度化しつつある現在, 二次元モデル, 準 三次元モデル, 三次元モデルの再現性の比較研究が改め て必要な時期にきていると考えられる.

モデルの適切な選択が重要となってくる場面の一つに水 害対策が挙げられる. 堤防や水制の設計などの事前対策の 段階ではできるだけ詳細な検討を実施することが好ましく, 三次元モデルが適しているといえるが, 洪水時の即時対応 システム等に用いるモデルは現象の進行の数倍速い速度 でシミュレーションを進めることが要求されるため, 二次元以 
下のモデルによらざるを得ない. 近年の水害の特徴の一つ として, 橋梁の上流側での溢水や破堤が挙げられる.これ は橋脚による水位の堰き上げに起因するものであり, 早急 な対策が望まれる。

本研究は橋脚による水位堰き上げ効果の再現性につい て, 二次元モデル(2D), 準三次元モデル(quasi-3D), 三次 元モデル(full-3D)の比較を行うものである. 二次元モデルと しては, 今回は二次流や鉛直加速度の影響を含まない単純 モデルについてのみ検討している. まず, 検証実験はとし て正方形断面の角柱を用いた実験を行い, 実験と同条件で 計算を行うことによりモデルの妥当性を評価する.

\section{2. 数值解析モデルの概要}

\section{（1）三次元モデル (full-3D Model)}

\section{a）基礎式}

水面変動を考慮するため, 次のような移動一般曲線座 標系の基礎式を用いる ${ }^{4)}$. 式の誘導の詳細は文献りに譲る. [連続式]

$$
\frac{1}{\sqrt{g}} \frac{\partial V^{\alpha} \sqrt{g}}{\partial \xi^{\alpha}}=0
$$

[運動方程式]

$$
\begin{aligned}
\frac{\partial V^{i}}{\partial t} & +\nabla_{j}\left[V^{i}\left(V^{j}-W^{j}\right)\right]+V^{i} \nabla_{j} W^{j}+V^{j} \nabla_{j} W^{i} \\
& =F^{i}-\frac{1}{\rho} g^{i j} \nabla_{j} p+\nabla_{j}\left[-\overline{v^{i} v^{j}}\right]+2 \nu \nabla_{j} S^{i j}
\end{aligned}
$$

[k- $\varepsilon$ 方程式]

$$
\begin{aligned}
& \frac{\partial k}{\partial t}+\nabla_{j}\left[k\left(V^{j}-W^{j}\right)\right]+k \nabla_{j} W^{j} \\
&=-g_{i l} \overline{\nu^{l} v^{j}} \nabla_{j} V^{i}-\varepsilon+\nabla_{j}\left\{\left(\frac{D_{t}}{\sigma_{k}}+\nu\right) g^{i j} \nabla_{i} k\right\}
\end{aligned}
$$

$\frac{\partial \varepsilon}{\partial t}+\nabla_{j}\left[\varepsilon\left(V^{j}-W^{j}\right)\right]+\varepsilon \nabla_{j} W^{j}=-C_{\varepsilon 1} \frac{\varepsilon}{k} g_{l} \overline{v^{l} v^{j}} \nabla_{j} V^{i}$

$-C_{\varepsilon 2} \frac{\varepsilon^{2}}{k}+\nabla_{j}\left\{\left(\frac{D_{t}}{\sigma_{k}}+v\right) g^{i j} \nabla_{i} \varepsilon\right\}$

ここに, $\xi^{j}$ : 計算空間の空間座標, $t$ : 時間, $V^{j}$ : 流速べ クトルの反変成分, $\mathrm{W}^{j}$ : 格子移動速度ベクトルの反変成 分, $v^{j}$ : 乱れ速度ベクトルの反変成分, $p$ : 圧力, $v$ : 動 粘性倸数, $\rho$ : 流体の密度, $k$ : 乱れエネルギー, $\varepsilon$ : 乱 れエネルギ一散逸率, $F^{j}$ : 重力ベクトルの反変成分をそ れぞれ表わす. $g_{\mathrm{ij}}, g^{\mathrm{ij}}$ は計量テンソルの共変成分及び反変 成分であり, 次のような関係がある.

$$
g_{i j}=\frac{\partial x^{k}}{\partial \xi^{i}} \frac{\partial x^{l}}{\partial \xi^{j}} \delta_{k l}, g^{j}=\frac{\partial \xi^{k}}{\partial x^{i}} \frac{\partial \xi^{l}}{\partial x^{j}} \delta_{k l}, g_{i j} g^{j k}=\delta_{i}^{k}
$$

ここに， $x^{j}$ はデカルト座標系を表す．また，

$$
g=\operatorname{det}\left[g_{i j}\right]
$$

である. さらに， $\nabla_{\mathrm{j}}$ は共変微分を表し，例えば，あるべ クトルの反変成分 $A^{\mathrm{k}}$ に関しては, 次のようになる.

$$
\nabla_{i} A^{k}=\partial A^{k} / \partial \xi^{i}+A^{j} \Gamma_{i j}{ }^{k}
$$

ここに， $\Gamma_{\mathrm{i} j}{ }^{\mathrm{k}}$ はクリストッフェルの記号（接続の係数）
であり，次式で計算される。

$$
\Gamma_{i j}{ }^{k}=\left\{\begin{array}{c}
k \\
i j
\end{array}\right\}=\frac{1}{2} g^{k m}\left(\frac{\partial g_{j m}}{\partial \xi^{i}}+\frac{\partial g_{i m}}{\partial \xi^{j}}-\frac{\partial g_{i j}}{\partial \xi^{m}}\right)=\frac{\partial \xi^{k}}{\partial x^{p}} \frac{\partial^{2} x^{p}}{\partial \xi^{i} \partial \xi^{j}}
$$

なお, 流速ベクトルの反変成分 $\left(V^{k}\right)$ と直交成分 $\left(U^{k}\right)$ は次 の関係 (chain rule) により変換される.

$$
V^{i}=\left(\partial \xi^{i} / \partial x^{j}\right) \cdot U^{j}, \quad U^{i}=\left(\partial x^{i} / \partial \xi^{j}\right) \cdot V^{j}
$$

b) 乱流モデル

乱流モデルには, 二次流や剥離渦の再現性, 壁面が粗 面である点を考慮して, 著者らが開発を行ってきた高レ イノルズ数型二次非線形 $k$-モモデルを用いる ${ }^{6}$. 本モデル は複断面開水路流れの大規模水平洞 ${ }^{7}$ など非定常組織渦 現象への適用性も検証されている. 非線形k-モモデルの 一般曲線座標系における構成則を次に示す.

$$
\begin{gathered}
-\overline{v^{i} v^{j}}=D_{t} S^{i j}-\frac{2}{3} k g^{i j}-\frac{k}{\varepsilon} D_{t}\left[\alpha_{1} Q_{1}+\alpha_{2} Q_{2}+\alpha_{3} Q_{3}\right] \\
D_{t}=C_{\mu} k^{2} / \varepsilon \\
Q_{1}=S^{i \alpha} g_{\alpha l} \Omega^{l j}+S^{j \beta} g_{\beta l} \Omega^{l i} \\
Q_{2}=S^{i \alpha} g_{\alpha l} S^{l j}-S^{k \alpha} g_{\alpha m} S^{m \beta} g_{\beta k} \delta_{l}^{i} g^{l j} / 3 \\
Q_{3}=\Omega^{i \alpha} g_{\alpha l} \Omega^{l j}-\Omega^{k \alpha} g_{\alpha m} \Omega^{m \beta} g_{\beta k} \delta_{l}^{i} g^{l j} / 3 \\
S^{i j}=g^{j \alpha} \nabla_{\alpha} V^{i}+g^{i \alpha} \nabla_{\alpha} V^{j}, \Omega^{i j}=g^{j \alpha} \nabla_{\alpha} V^{i}-g^{i \alpha} \nabla_{\alpha} V^{j}
\end{gathered}
$$

モデル係数は，ストレインパラメータSと，ローテイ ションパラメータ $\Omega$ 次のような関数で与える.

$\alpha_{1}=-0.1325 f_{M}, \quad \alpha_{2}=0.0675 f_{M}, \alpha_{3}=-0.0675 f_{M}(16)$

$$
\begin{gathered}
f_{M}=\left[1+0.02 M^{2}\right]^{-1}, \quad M=\max [S, \Omega] \\
C_{\mu}=\min \left[0.09, \quad 0.3 /\left(1+0.09 M^{2}\right)\right] \\
S=\frac{k}{\varepsilon} \sqrt{\frac{1}{2} S^{i \alpha} g_{\alpha j} S^{j \beta} g_{\beta i}}, \Omega=\frac{k}{\varepsilon} \sqrt{\frac{1}{2} \Omega^{i \alpha} g_{\alpha j} \Omega^{j \beta} g_{\beta i}}
\end{gathered}
$$

モデル係数のうち式(16)，（17) は単純せん断流場におけ る乱れ強さの配分に関する実験結果との比較を通じて同 定された. 式(18)については文献)のように，二次元及 び三次元流れにおける実現条件から同定した.

\section{c) 計算スキーム}

計算法は有限体積法とし, 安定性と有限体積法への親 和性を考慮して, 圧力, $k$ およびをを直方体格子の中央で, 流速ベクトルの成分を側面で定義する完全スタガード格 子系を用いる. 計量テンソル, クリストッフェル記号等 は格子点上で定義し, 計算の過程で必要となる位置の值 については, その都度内挿により求めた。 これは, 計算 機記憶容量の節約のためである.

運動方程式の移流項の離散化にはQUICKを， $k$ および $\varepsilon$ 方程式の移流項にはHybrid法を用いた. また, 運動方程 式の移流項のクリストッフェル記号を含む付加項につい ても，従来の研究9にはならコントロールボリュームの 上流側で評価した。時間積分は完全陽解法とし，二次の Adams Bashforth法を用いる. 圧力は時間ステップ毎に SOLAアルゴリズムと同様の収束計算により求める. 図1に用いた計算格子の角柱近傍の平面図を示した.

\section{d）壁面及び水面の取り扱い}




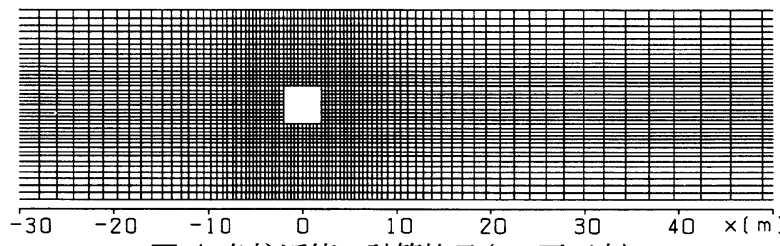

図-1 角柱近傍の計算格子 $(\mathrm{x}-\mathrm{y}$ 平面内)

表-1 流れ場の水理条件

\begin{tabular}{c|c|c|c|c|c|c}
\hline$h(\mathrm{~cm})$ & $U_{0}(\mathrm{~cm} / \mathrm{s})$ & $D(\mathrm{~cm})$ & $\mathrm{B} / \mathrm{D}$ & $\mathrm{h} / \mathrm{D}$ & $\mathrm{Re}$ & $\mathrm{Fr}$ \\
\hline 1.14 & 18.18 & 4.0 & 5 & 0.285 & 8400 & 0.54 \\
\hline
\end{tabular}

$\mathrm{h}$ : depth, $\mathrm{U}_{0}$ : mean velocity, D: side-length of cylinder B: channel width, Re: Reynolds number $\left(=\mathrm{U}_{0} \mathrm{D} / v\right)$, Fr: Froude number $\left(=\mathrm{U}_{0} / \sqrt{\mathrm{gh}}\right)$

今回の数值計算の対象が河川流であることを考慮し， 壁面の $k$ とにについては壁関数法で与え, 壁面近傍の流速 は対数則で評価することとした。

水面の\&は杉山ら ${ }^{10)}$ の提案する次式で評価した。

$$
\varepsilon_{s}=C_{\mu 0}{ }^{3 / 4} k_{s}^{3 / 2} /\left(0.4 \Delta z_{s}\right), \quad\left(C_{\mu 0}=0.09\right)
$$

上式中，添字 $\mathrm{s}$ は表層の值を， $\Delta z_{\mathrm{s}}$ は水面から定義点ま での距離を表す. 水面の $k$ にはslip条件を課す。 また，水 面近傍の鈆直方向の乱れの減衰を考慮するため, 次の減 衰関数を渦動粘性係数に乗じる ${ }^{11}$.

$$
f_{s}=1-\exp \left\{-B(h-z) \varepsilon_{s} / k_{s}^{3 / 2}\right\}, \quad(B=10)
$$

自由水面変動量は, 反変成分表示の基礎式においては次 のように極めて簡単な式により計算される ${ }^{9)}$.

$$
\Delta h=\sqrt{g_{33}} V^{3} \Delta t
$$

上の式で, $\Delta \mathrm{t}$ : 計算時間間隔, $\Delta h: \Delta t$ 時間の水面変動量 を表し，添字 3 は鈆直方向を表わすものとする.

\section{（2）準三次元モデル(Quasi-3D Model)}

静水圧近似により鉛直方向の運動方程式は,

$$
g^{3 j} \nabla_{j} p=\rho F^{3}
$$

と簡略化される. これに伴い, 圧力の収束計算は不要と なる. その他については三次元モデルと同様である.

\section{（3）平面二次元モデル(2D Model)}

\section{a）基礎式}

水深積分されたデカルト座標系による次式を用いる.

$$
\begin{gathered}
\frac{\partial h}{\partial t}+\frac{\partial M}{\partial x}+\frac{\partial N}{\partial y}=0 \\
\frac{\partial M}{\partial t}+\frac{\partial \beta u M}{\partial x}+\frac{\partial \beta v M}{\partial y}+g h \frac{\partial h}{\partial x}=g h \sin \theta-\frac{\tau_{b x}}{\rho}+ \\
\frac{\partial\left(-\overline{u^{\prime 2}} h\right)}{\partial x}+\frac{\partial\left(-\overline{u^{\prime} v^{\prime} h}\right)}{\partial y}+v\left[\frac{\partial}{\partial x}\left(h \frac{\partial u}{\partial x}\right)+\frac{\partial}{\partial y}\left(h \frac{\partial u}{\partial y}\right)\right] \\
\frac{\partial N}{\partial t}+\frac{\partial \beta u N}{\partial x}+\frac{\partial \beta v N}{\partial y}+g h \frac{\partial h}{\partial y}=-\frac{\tau_{b y}}{\rho}+\frac{\partial\left(-\overline{u^{\prime} v^{\prime}} h\right)}{\partial x} \\
+\frac{\partial\left(-\overline{v^{\prime 2}} h\right)}{\partial y}+v\left[\frac{\partial}{\partial x}\left(h \frac{\partial v}{\partial x}\right)+\frac{\partial}{\partial y}\left(h \frac{\partial v}{\partial y}\right)\right]
\end{gathered}
$$

ここに, $h:$ 水深, $(u, v)$ : 水深平均流速べクトルの $\mathrm{x}, \mathrm{y}$ 方向成分, $(M, N)$ : 流量フラックス $(M=h u, N=h v)$; $-\overline{u_{i}{ }^{\prime} u_{j}{ }^{\prime}}$ : 水深平均レイノルズ応カテンソル $\left(u_{1}{ }^{\prime}=u\right.$,

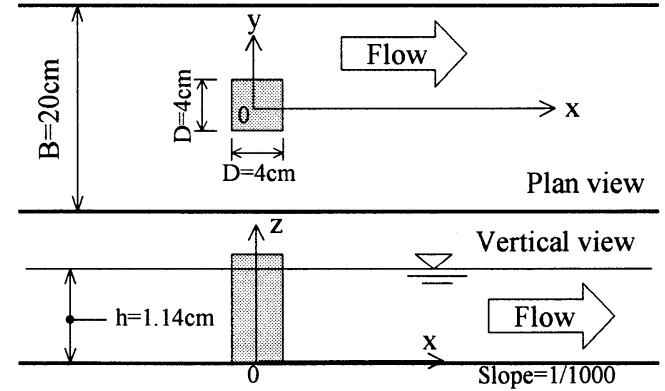

図-2 流れ場の模式図

$\left.u_{2}^{\prime}=v^{\prime}\right) ;\left(\tau_{\mathrm{bx}}, \tau_{\mathrm{by}}\right)$ : 底面摩擦応力, $v$ : 動粘性係数, $\theta$ : 水路床勾配, $\beta$ : 運動量係数 (乱流では1.0, 層流では 1.2の值を用いた）をそれぞれ表す。

底面摩擦応力については次のように評価した。

$$
\tau_{b x}=\frac{f \rho u}{2} \sqrt{u^{2}+v^{2}} ; \quad \tau_{b y}=\frac{f \rho v}{2} \sqrt{u^{2}+v^{2}}
$$

ここに，fは摩擦係数であり，局所的なレイノルズ数 $R_{e}$, $\equiv u h / v$ の関数として次のように与えられる.

$$
f=6 / R_{e}{ }^{\prime}, \quad\left(R_{e}{ }^{\prime} \leq 430\right)
$$

$\sqrt{2 / f}=A_{S}-\left[1-\ln \left(R_{e}{ }^{\prime}-\sqrt{f / 2}\right)\right] / \kappa, \quad\left(R_{e}{ }^{\prime}>430\right)$

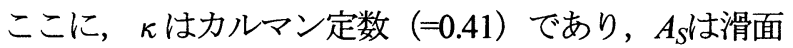
乱流で一般的に用いられる定数5.5を用いた

b) 乱流モデル

レイノルズ応力は次の線形構成則で表す.

$$
-\overline{u_{i}{ }^{\prime} u_{j}{ }^{\prime}}=D_{t}\left(\frac{\partial u_{i}}{\partial x_{j}}+\frac{\partial u_{j}}{\partial x_{i}}\right)-\frac{2}{3} k \delta_{i j}
$$

ここに，kは水深平均乱れエネルギーであり， $\delta_{\mathrm{ij}}$ はクロ ネッカーのデルタである. $k$ については次のNeze \& Nakagawa $^{12)}$ の半理論式を水深積分した次式で評価する.

$$
k=\gamma_{k} u_{*}^{2}, \quad \gamma_{k}=2.07
$$

渦動粘性係数は次のゼロ方程式モデルで評価する3).

$$
D_{t}=\alpha h u_{*}
$$

$\alpha$ はストレインパラメータ等の関数とするモデルも提案 されているが ${ }^{3)}$ ，ここでは簡単に定数 (=0.2) とおく.

基礎式の離散化や境界条件等は三次元モデルに準じる.

\section{3. モデルの再現性の比較}

\section{（1）検証実験の概要}

検証実験は，既往の実験13) と同条件で行った．幅 $20 \mathrm{~cm}$, 長さ $10 \mathrm{~m}$ ，勾配 $1 / 1000$ の可傾斜開水路を用い，水路の中 央付近に一辺が $4 \mathrm{~cm}$ の角材を設置し，通水した． 既報 ${ }^{13)}$ では水深の中点における流速をプロペラ流速計を用いて 計測しており，今回は水深の計測のみ行った．計測には ディジタルポイントゲージを用いている. 実験の条件を 表-1に，流れ場の概要と座標系を図-2に示した.

\section{（2）再現性の比較}

\section{a) 時間平均流特性の比較}

図-3は数值解析における時間平均流速べクトルである. 

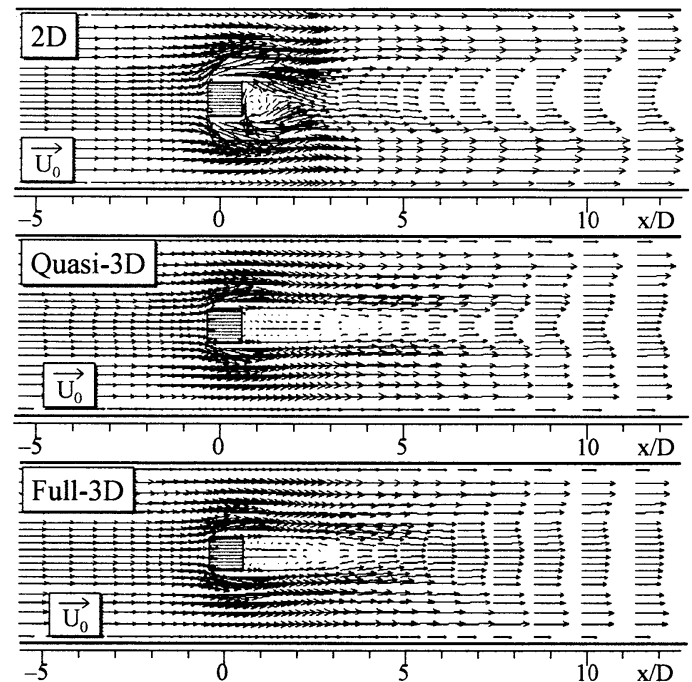

図-3 水平面内の時間平均流速ベクトル

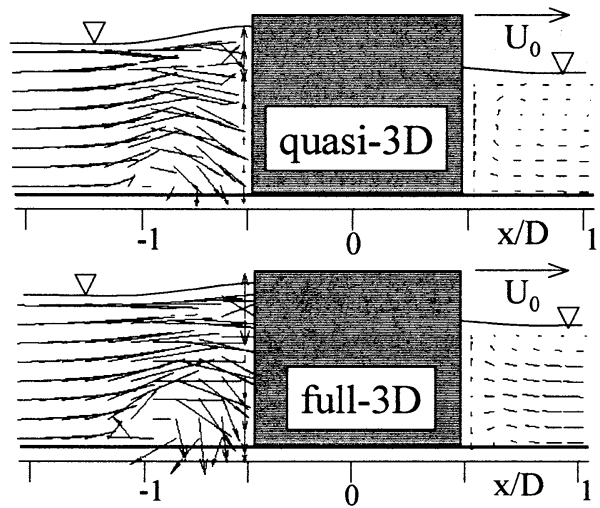

図-4 鉛直縦断面内の時間平均流速ベクトル $(\mathrm{y} / \mathrm{D}=0, \mathrm{x}-\mathrm{z}$ 平面 $)$

角柱下流側の再循環流域の長さに明確な差が見られ，二 次元モデルが最小，準三次元モデルが最大となっている． 図-4は，角柱近傍のx軸に沿う鉛直維断面内の時間平均 流速場を準三次元モデルと三次元モデルで比較したもの であり，鉛直スケールを 2 倍に拡大して示している.い ずれのモデルでも角柱上流側底面付近に時計回りの渦が みられる。これは，馬蹄渦の上流端に相当するものであ る. 渦の再現性にもモデルによる差異が認められ，渦の 直径や回転流速は三次元モデルの方が大きい.

\section{b) 非定常特性の比較}

実験では後流域にカルマン渦がみられ，数值解析にお いても全てのモデルでカルマン渦が再現された. 図-5は瞬 間的な流速べクトルを比較したもので, 再循環流域の長さに 影響され, 二次元モデルの渦の発振位置が最も角柱に近 づいている. 渦特性を更に検討するため, 角柱の下流側の 2点(位置は図中に表示)の主流方向流速の時系列を, 実験, 二次元モデル, および三次元モデルで比較したのが図-6 である. 実験のStrouhal数は0.24であり, 数值解析のStrouhal 数はいずれのモデルでも実験值とほぼ一致している. 実験 では水路中心付近の周期に比べて中心軸を逸れた点 (y/D=1.5)の周期が長いことがわかる. 二次元, 三次元モデ ルはともにこのような特性を捕らえているが, 二次元モデル はy/D=1.5における振幅が実験に比べて相当大きい. 三次

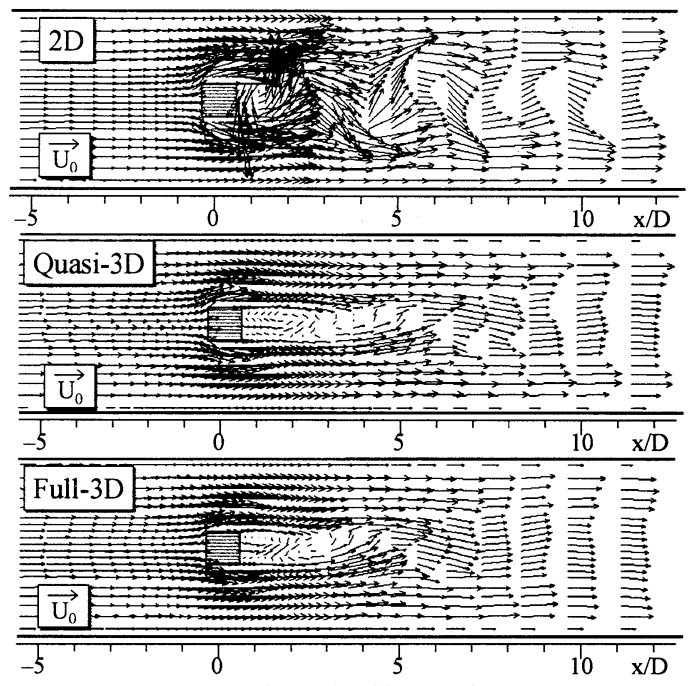

図-5 水平面内の瞬間的な流速ベクトル

元モデルは2地点の振幅, 周期をほぼ良好に再現している. c）三次元モデルによる動水圧分布の検討

図一流, 三次元モデルにおける動水圧(静水圧からの偏 差)の分布を示したものであり, 上は水深の中点の位置の平 面分布を，下はx軸に沿う鉛直繸断面の分布をそれぞれ示 している. なお, 鉛直分布については鉛直スケールを水平 スケールの6倍に拡大して示している. まず, 平面図につい てみると, 角柱の直上流は正の動水圧がみられるが, その 上流側のU字型の馬蹄渦に沿つた領域では負の值となって いる.これは馬蹄渦の中心付近で遠心力の影響を受けるた めと考えられる. 角柱の側壁に沿った馬蹄渦より内側の箇 所は, 正の分布となっている. 一方, 角柱直下流側の左右 の剥離域でも負の動水圧がみられる. 鉛直分布についてみ ると, 角柱の上流側の馬蹄渦付近の広い範囲で負の分布が みられる.この付近は角柱に衝突した流れが左右に分岐し て進む鞍形点ともなっており, 圧力の急激な低下が生じて いることがうかがえる. 馬蹄渦の周囲では逆に正の動圧分 布がみられる. 今回の実験においては圧力の計測を行って いないため, 実現象との比較はできないが, 流れ場との関 連を考えると定性的には妥当な分布といえそうである。

\section{d）角柱周辺の水位変動に関する比較}

図-8は，3つのモデルによって再現された水面変動の 20 秒間の時間平均值である. 二次元モデルで左右非対称 となるのは比較的長周期の変動の存在による. 一見して, 二次元モデルが角柱下流側の水面の窪みを最も大きく再 現しており, 準三次元モデルは角柱下流側の水面形が最 も平坦である. より定量的特性を検討するため, $\mathrm{x}$ 軸方向の 水面形分布を, $y / D=0, y / D=1.502$ 断面について, 図-9に示 した. $\mathrm{y} / \mathrm{D}=0$ 断面について，まず角柱下流側に着目すると， 二次元モデルは水深の低下を過剩に評価していることがわ かる. 準三次元および三次元モデルは, 逆に下流側の水深 低下を十分再現していない. 上流側の堰き上げに着目する と, いずれのモデルも実験值との適合は良好に見える. 角 柱上流の水深の最大值をみると, 実験が $1.45 \mathrm{~cm}$, 二次元モ デルが $1.45 \mathrm{~cm}$, 準三次元モデルが $1.42 \mathrm{~cm}$, 三次元モデル 


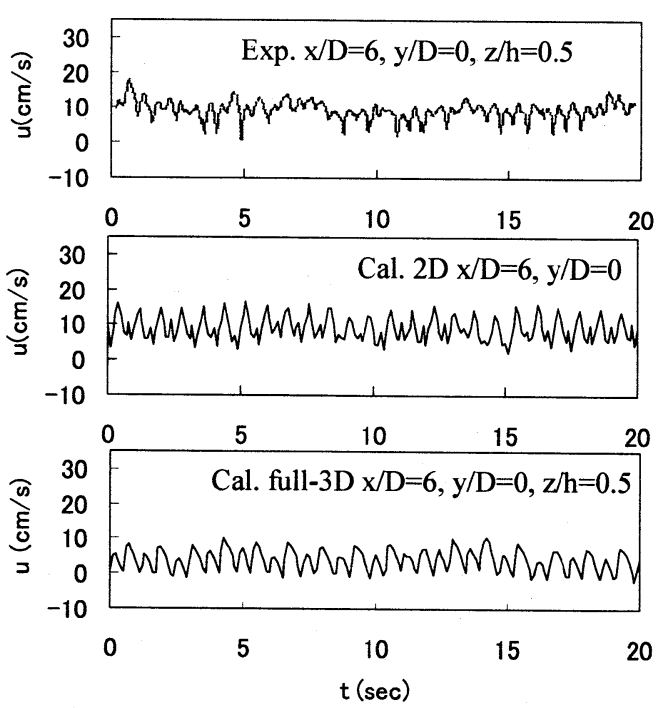

図-6（a）主流方向流速Uの時系列(中心軸上， $\mathrm{z} / \mathrm{D}=6$ )
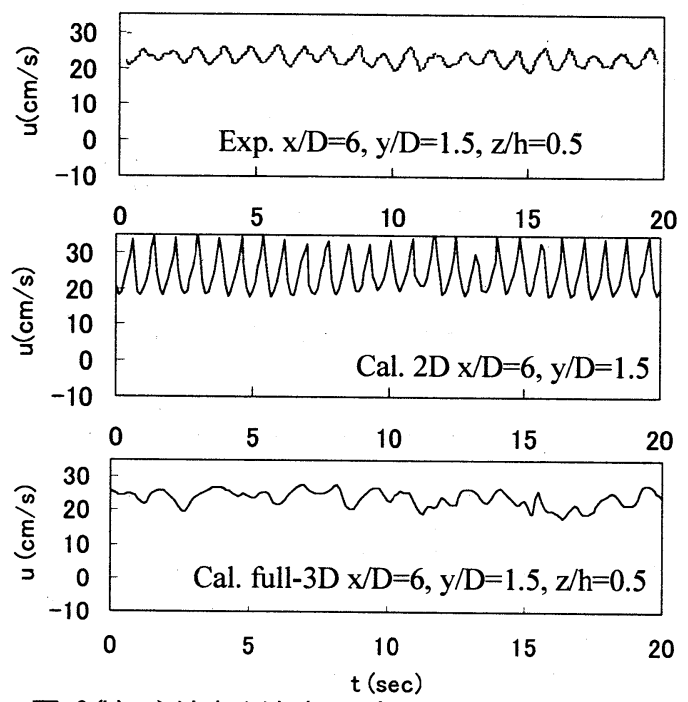

図-6(b) 主流方向流速Uの時系列 $\mathrm{y} / \mathrm{D}=1.5, \mathrm{z} / \mathrm{D}=6$ )

が $1.45 \mathrm{~cm}$ であり, 準三次元モデルの再現性が若干劣ってい る.一方, 角柱から離れた $\mathrm{y} / \mathrm{D}=1.5$ の断面では二次元モデ ルの結果が最も良好となった. 次に角柱前後の横断方向の 水面形を検討するため, $\mathrm{x} / \mathrm{D}=-1,1$ の 2 つ断面の水深分布 を図-10に示した. 角柱上流側 $(\mathrm{x} / \mathrm{D}=-1)$ では, いずれのモデ ルも水面形をよく表しているが, わずかながら二次元モデル は水深を過大評価, 準三次元モデルは過小評価している. 角柱下流側( $\mathrm{x} / \mathrm{D}=1)$ では二次元モデルが中心線付近の水 位低下を過㮃に再現している様子が再度示されている。

結局, 二次元モデルは水位変動(特に下流側の窪み)を 過大評価し, 準三次元モデルは水面形が最も平坦になると いう特性が示された. ただしこれらには計算格子や乱流モ デルの影響もあると考えられ，さらなる検討が必要である.

e) CPU時間の比較

本研究ではDual Xeon 2.4GHz, RAM:512MbのPCにより, OpenGLによる並列計算により計算を実行している. 各 モデルによる実時間10(s)の計算に要したCPU時間は, 二 次元モデルが1.7(min), 準三次元モデルが284(min), 三次 元モデルが364(min)であった.

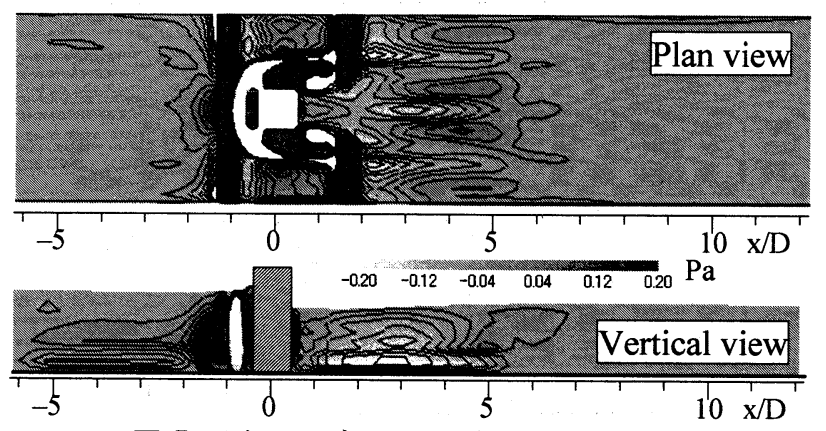

図-7 三次元モデルによる時間平均動圧分布

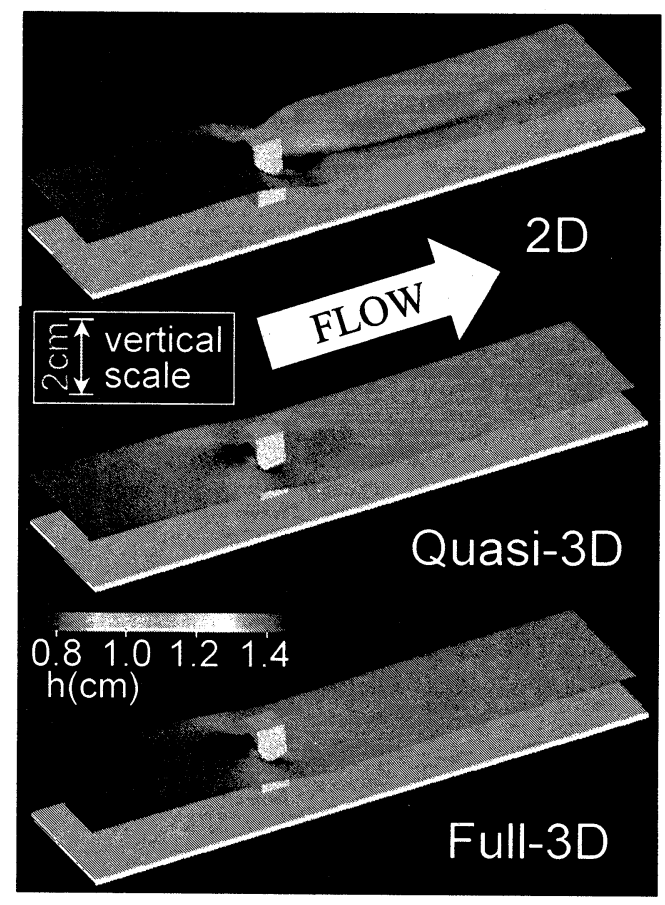

図-8 時間平均水面の鳥㒈図の比較

\section{4. まとめ}

本研究は, 角柱周辺の流れ場と水位変動に着目して, 二次元モデル, 準三次元モデル, 三次元モデルの比較を 行ったものである. 主な結果を次に列挙する.

1. 角柱下流側の再循環域は二次元モデルで最も短く, 三 次元モデル, 準三次元モデルの順で長くなった.

2. カルマン渦はいずれのモデルでも再現されるが，二 次元モデルでは角柱から離れた領域での流速の振幅 の減衰が小さかった。

3. 角柱周辺の水位変動は, 二次元モデルは過剩に再現, 準三次元モデルは過小に再現する傾向がみられた.

今回の結果では, 水位の再現性に関する二次元, 三次 元モデルの差異は比較的小さく，CPU洔間に100倍以上ひ) 差があることを考えると, 二次元モデルの害用性が際立 つ結果となった. 今後はさらに多くの条件で検討を実施 し，モデルの合理的な選択方法について検討を進めたい．

謝辞 : 本研究の遂行にあたり, 松江高専土木工学科 5 年 生, 渡辺陽子さん, 角由香里さんには実験の補助をいた だいたので，ここに記して謝意を表する. 

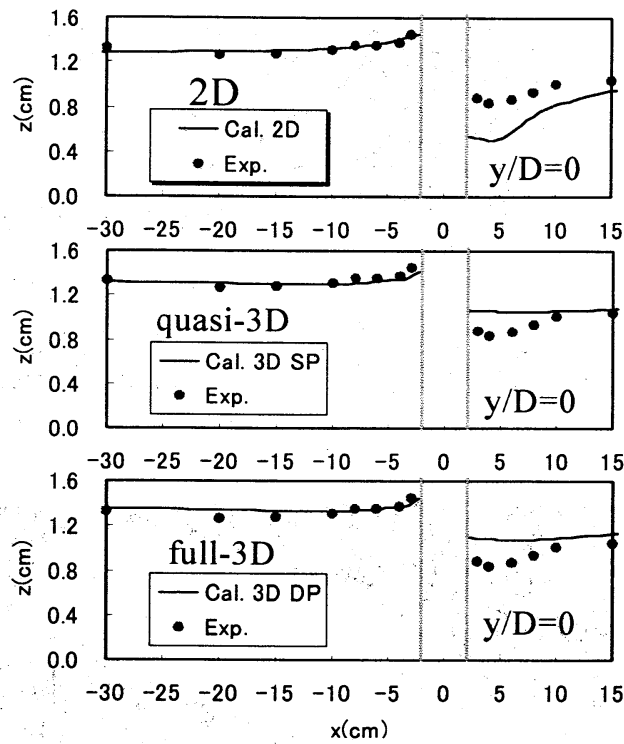

図-9（a）縦断面内の水面形の比較 $(\mathrm{y} / \mathrm{D}=0)$
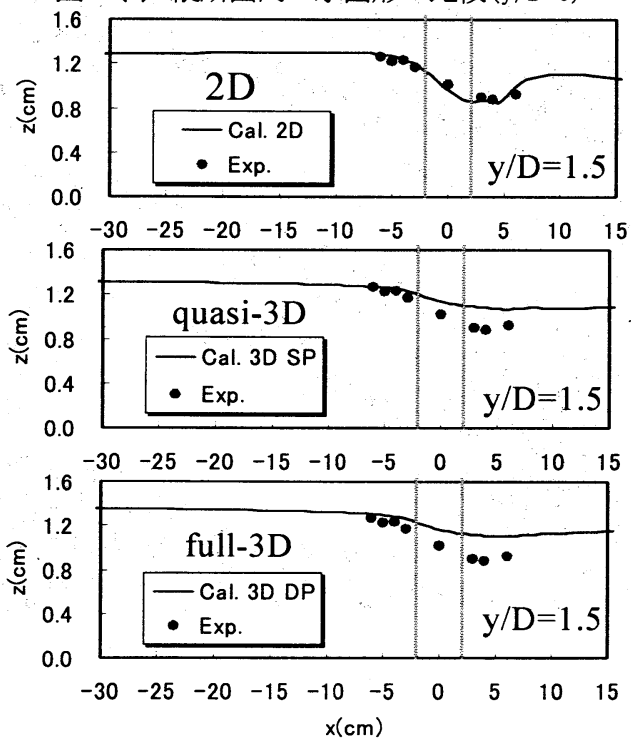

図-9 (b) 縦断面内の水面形の比較 ( $\mathrm{y} / \mathrm{D}=1.5)$

\section{参考文献}

1) Hosoda, T., Nagata, N, Kimura, I., Michibata, K. and Iwata, M. : A depth averaged model of open channel flows with lag between main flows and secondary currents in a generalized curvilinear coordinate system, Advances in Fluid Modeling \& Turbulence Measurements, World Scientific, pp.63-70, 2001.

2）細田尚，多田彰秀 : 鉛直加速度を考慮した基礎式系による 開水路流れの定在波の水面形解析，水工学論文集，第38巻, pp.457-462, 1994.

3）木村一郎, 細田尚 : 開水路せん断混合層の流れ構造に対寸 る水深積分型修正ゼロ方程式モデルの適用性, 水工学論文 集, 第48巻, pp.673-678, 2004.

4) 木村一郎, 細田尚, 音田慎一郎, 冨永晃宏 : 越流型水制周 辺の三次元乱流構造に及ぼす水理パラメータの効果, 水工 学論文集, 第48巻, pp.661-666, 2004.

5) 木村一郎, 細田尚, 音田慎一郎 : 完全スタガード移動一般 曲線座標系における開水路乱流シミュレータの開発, 四日市 大学環境情報論集, Vol.5, pp.145-170, 2002.

6) Kimura, I. and Hosoda, T. : A non-linear k- $\varepsilon$ model with realizability for prediction of flows around bluff bodies, International Journal for Numerical Methods in Fluids, Vol.42, pp.813-837, 2003.
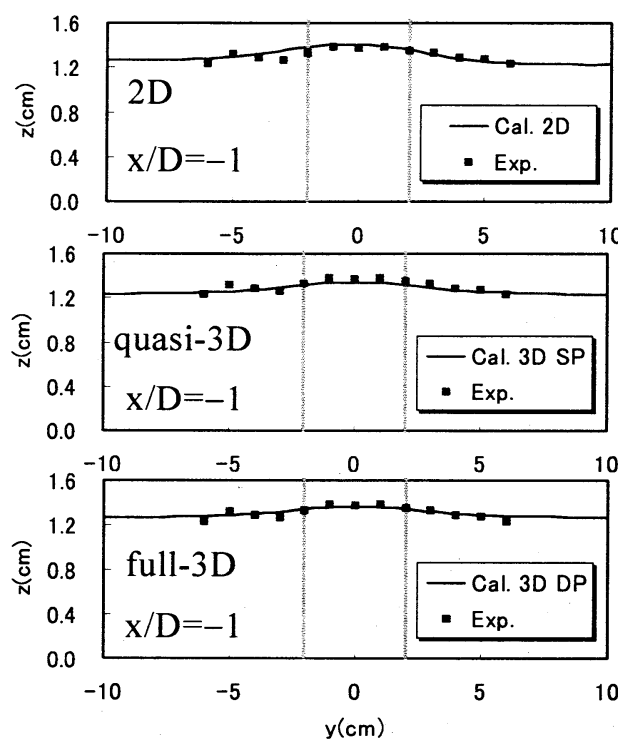

図-10（a）横断面内の水面形の比較 $(\mathrm{x} / \mathrm{D}=-1)$
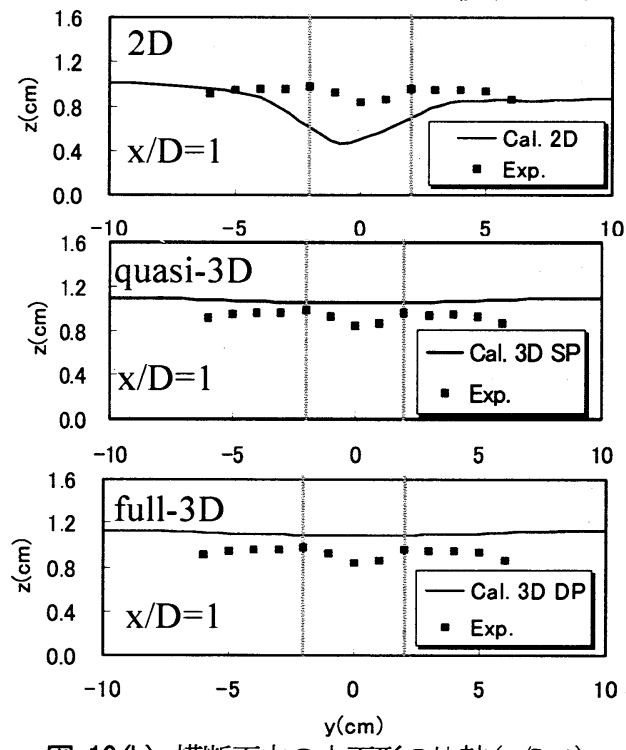

図-10 (b) 横断面内の水面形の比較 $(\mathrm{x} / \mathrm{D}=1)$

7) Kimura, I., Hosoda, T. and Sakurai, T.: Prediction of flow characteristics in compound open channels by means of a non-linear k- $\varepsilon$ model, Proc. 3rd ISEH, Tempe, USA, (CD-ROM), 2001.

8) Hosoda, T., Kimura, I. and Shinichiro, O. : Some necessary conditions for a non-linear $k-\varepsilon$ model in classified flow patterns with a singular point, Proc. $2^{\text {nd }}$ Internatilnal Symp. on Turbulence and Shear Flow Phenomena, Stockholm, Vol.3, pp.155-160, 2001.

9) Takizawa, A., Koshizuka, S. and Kondo, S. : Generalization of physical component boundary fitted co-ordinate (PCBFC) method for the analysis of free-surface flow, International Journal for Numerical Methods in Fluids, Vol.15, pp.1213-1237, 1992.

10) 杉山均, 秋山光庸, 松原珠: 複断面開水路内の乱流構造解析 と縦渦生成に関する研究, 土木学会論文集, Vol.515，II -31, pp.55-65, 1995.

11) 細田尚 : 開水路流れにおける乱流拡散機構に関する水理学 的研究, 京都大学博士論文, 1990 .

12) Nezu, I. and Nakagawa, H.: Turbulence in open channel flows, IAHR Monograph, Belkema, Rotterdam, Netherlands, 1993.

13）木村一郎, 細田尚 : 非線形k-eモデルによる開水路流れに おける大規模渦運動の三次元解析, 四日市大学環境情報論 集, Vol.2, No.2, pp.135-162, 1999.

(2004.9. 30 受付) 